\title{
METODOLOGI TAFSIR KONTEKSTUAL AL-AZHAR KARYA BUYA HAMKA
}

\author{
Husnul Hidayati \\ Universitas Islam Negeri (UIN) Mataram \\ Email: husnulhidayati@uinmataram.ac.id
}

\begin{abstract}
Abstrack: This paper discusses one of the books of Indonesia Tafseer, namely Tafseer Al-Azhar by Hamka. This writing uses descriptive-analytical methods with historical-hermeneutical approach. Some important points to be disclosed about the Tafser Al-Azhar include: the first, Tafsir Al-Azhar methods and steps of compilation Tafser Al-Azhar is tahlili-mushafi with colors and indonesian shades very thick or better known as the term adabijtima'i. Second, Hamka is very keen to invite Muslims in voicing contextual interpretation, an interpretation that is in harmony with the circumstances and the development of the times. This is a reality, Hamka has actually applied hermeneutic effort in his work. Because after all, the concept of hermeneutics-in a narrow sense-is an attempt to recite the Qur'an which not only provides a textual meaning of a verse but provides a reproduction of a verse to the state (reality) in which the Qur'an is interpreted . With this method invites to a more contextual-universal understanding of the Qur'an.
\end{abstract}

\begin{abstract}
Abstrak: Tulisan ini membahas salah satu kitab tafsir Indonesia, yakni Tafsir Al-Azhar karya Hamka. Penulisan ini menggunakan metode deskriptif-analitif dengan pendekatan sejarah-hermeneutis. Beberapa point yang penting untuk diungkapkan mengenai Tafsir Al-Azhar diantaranya: Petama, Tafsir Al-Azhar metode dan langkah
\end{abstract}


penyusunan Tafsir Al-Azhar adalah tahlili-mushafi dengan warna dan corak keindonesiaan yang sangat kental atau lebih dikenal dengan istilah corak adab ijtima'i. Kedua, Hamka sangat getol mengajak umat Islam dalam menyuarakan tafsir kontekstual, tafsir yang selaras dengan keadaan dan perkembangan zaman. Dengan kenyataan tersebut, sebenarnya Hamka telah mengaplikasikan upaya hermeneutika dalam karyanya tersebut. Karena bagaimanapun, konsep hermeneutika-dalam makna yang sempit-merupakan usaha pembacaan al-Qur'an yang tidak hanya memberikan pemaknaan terhadap tekstual suatu ayat, namun memberikan pemkanaan kembali (reproduksi) suatu ayat terhadap keadaan (realita) dimana al-Qur'an ditafsirkan. Dengan metode tersebut mengajak kepada pemahaman al-Qur'an lebih kontekstual-universal

Key Word: Tafsir Indonesia, Hamka, Tafsir Al-Azhar, Tekstual, Kontekstual

\section{A. Pendahuluan}

Indonesia, sebagai negara dengan penduduk Muslim terbesar dunia, tentunya- sebenarnya- tidak kalah dengan negara-negara Islam semisal Mesir, Iran, dan lainnya dalam hal ilmu dan pemikiran keislaman (dirasah al-Islamiyyah). Namun, fakta berbicara berbeda. Indonesia 'seakan-akan' sulit melahirkan tokoh at au ulama (khususnya dalam bidang tafsir dan hadis) se'populer' Sayyid Qutb, ${ }^{1}$ Fazlur Rahman $^{2}$ dan yang lainnya.

1 Fazlur Rahman lahir pada tahun 1919 tepatnya tanggal 21 September, di daerah hazara yang terletak di wilayah Barat Laut Pakistan. Mufassir kontemporer ini dikenal dengan teori Double Movement. Diantara karyanya yang sering menjadi kajian adalah Major Themes of the Qur'an(Minneapolis Bibliotheca Islamica, 1980). Lebih jelasnya, lihat Abdul Mustaqim, Epistemologi Tafsir Kontemporer (Yogyakarta: Lkis. 2012).

2 Sayyid Qutb Dilahirkan di kota Asyut, Mesir, pada tanggal 9 oktober 1906. Salah satu karyanya yang sangat popular dan menjadi bahan kajian masyarakat dan ormas-ormas Islam juga Indonesia adalah Tafsir Fi Zhilal al-Qur'an. Tafsir yang ditulisanya selama mendekam di penjara. Lihat, Muhammad Chirzin, Sayyid Qutb dan al-Taswir al-Fanni fi al-Qur'an (Penggambaran Artistik dalam al-Qur'an) dalam Jurnal Studi Ilmu-Ilmu al-Qur'an dan Hadis. Vol. III, No. 2, Januari 2003. $132-133$ 
Banyak faktor yang menyebabkan keremang-remangan intelektual Indonesia di mata dunia tersebut, disatu sisi media elektronik mungkin bisa menjadi faktor eksternal yang agak lambat datang ke Indonesia, namun disisi lain adalah adanya keengganan untuk menduniakan pemikiran tokoh Indonesia, ini bisa dibuktikan dengan pihak akademisi Indonesia lebih gandrung dan loyal dalam memperkenalkan tokoh yang sudah ditokohi, namun-cenderungmelupakan pengaruh dan karya ulama pribumi sendiri. ${ }^{3}$

Karenanya, tulisan sederhana ini berusaha untuk menyuarakan salah satu tafsir Indonesia, Tafsir Al-Azhar yang merupakan mognum opus Hamka. Penelitian ini bersifat library research dengan metode deskriptif akan membahas seluk-beluk Tafsir Al-Azhar dengan segala macam kaidah penelitian terhadap suatu karya dan pemikiran yang ada.

\section{B. Sktesa Singkat Hamka}

Abdul Malik adalah nama kecil dari penulis Tafsir al-Azhar, ia lahir di Sungai Batang Maninjau-Sumatera Barat, pada 16 Februari 1908 M./13 Muharram 1326 H. ${ }^{5}$ Abdul Malik kemudian lebih dikenal

3 Pernyataan serupa sebenarnya sudah pernah dilontarkan oleh Gus dur. Sampai saat ini, Indonesia telah melahirkan puluhan bahkan ratusan ulama kelas Internasional. Syekh Nawawi al-Banteni misalkan, dikenal dengan pemuka ulama' Hijaz, Sayyid 'Ulama' al-Hijaz yang telah berhasil menegakkan supremasi penguasaan ilmu agama Islam. Kyai Ihsan Kediri dengan karya monumentalnya Siraj Al-Thalibin (syarah dan komentar Minhaj al- 'Abidin karya al-Ghazali) sampai saat ini sebagai kajian utama, textbook di Pascasarjana di seluruh dunia, termasuk Al-Azhar University dan Nigeria University, tapi anehnya sat upun perguruan tinggi di Indonesia tidak ada yang menjadikannya kajian ilmiah tetap. Abdurrahman Wahid "Benarkah Buya Hamka Seorang Besar? Sebuah Pengantar" dalam Nasir Tamara (ed), Hamka Di Mata Hati Umat (Jakarta: PT Sinar Agape Press. 1984)

4 Kehadiran buku-buku baik berupa otobiografi, biografi serta ringkasan kehidupan Hamka dalam ragam laporan penelitian sudah sangat banyak mendapat perhatian dari kaum akademis, ini tentunya sangat membantu dalam penelusuran sosok Hamka lebih jauh, namun disini akan diulas seperlunya untuk dikutip. Buku dimaksud dapat dibaca seperti Hamka, Kenang-kenangan Hidup yang terdiri dari empat jilid cetakan Bulan Bintang, Jakarta. Juga, Rusydi, Martabat dan Pribadi Prof. Dr. Buya Hamka, Jakarta: Panjimas, 1983. Dan tesis Mukhlis yang terbitkan dengan judul Inklusifisme tafsir Al-azhar, Mataram: IAIN Mataram Press.2004

5 Terdapat dua pendapat mengenai tanggal kelahiran Hamka, selain tanggal diatas ada yang mengatakan tanggal kelahirannya adalah 17 Februari pada tahun yang sama. "Nama Saya: Hamka", dalam Nasir Tamara, Buntaran Sanusi, dan Vincent 
dengan nama Hamka yang sebenarnya merupakan akronim dari Haji Abdul Malik Karim Amrullah.

Mengingat ayahnya(Haji Rasul) adalah seorang tokohpembaharu di Sumatera Barat, tidak mengherankan jika Hamka lahir dan tumbuh dalam suasana pembaharuan yang diperjuangkan ayahnya sejak tahun 1906 di Minangkabau-yakni setelah ayahnya kembali dari menuntut ilmu di Mekkah pada Syekh Ahmad Khatib- akibatnya, ketegangan dan polarisasi sosial akibat penolakan 'orang tua' terhadap ide pembaruan 'kaum muda' ${ }^{6}$ yang dipelopori ayahnya juga ikut membentuk jati diri Hamka pada masa mendatang. ${ }^{7}$

Hamka masuk SD (Sekolah Desa) ketika memasuki delapan tahun (1916). Oleh ayahnya, dia juga dimasukkan ke sekolah Diniyah, yang didirikan oleh Zainudin Lebay El-Yunusi. ${ }^{8}$ Tidak lama kemudian, Hamka ditarik dari Sekolah Desa dan dialihkan ke Madrasah TawalibMadrasah ini tidak lain embrionya adalah surau tempat ayahnya mengajar- hal ini dimaksudkan ayahnya untuk menggembleng Hamka menjadi ulama' besar dimasa mendatang. Menurut penuturan Hamka, pelajaran-pelajaran yang diberikan didua lembaga pendidikan itu tidak ada yang menarik hatinya, kecuali pelajaran 'Arudl, timbangan sya'ir 'Arab. ${ }^{9}$ Hal ini rupanya merupakan manifestasi dari kecenderungan jiwanya kepada dunia sastera dan kepujanggaan.

Menginjak usia tahun ke-16, Hamka rihlah ke tanah Jawa, tepatnya Yogyakarta dan Pekalongan (1924-1925). Rihlah tersebut pada akhirnya membawa dampak besar terhadap pola pandang keislaman Hamka. Di Yogyakarta, Hamka berkesempatan bertemu

Djauhari (Editor), Hamka di Mata Hati Umat, (Jakarta: Sinar Harapan, 1996), Cet. III, h. 51. Juga, Hamka, Kenang-kenangan Hidup (Jakarta: Bulan Bintang 1979), Jilid I, 9.

6 . Kaum muda tersebut pada awalnya dikenal dengan empat putera Minang, mereka adalah: Haji Abdul Karim Amrullah (ayah Hamka), Syaikh Taher Jalaludin, Syaikh Muhammad Djamil Djambek dan H. Abdullah Ahmad. Pada initinya pembaharuan yang mereka lakukan adalah untuk memurnikan Islam dai praktekpraktek agama yang tidak sesuai dengan tuntunan agama. Deliar Noer, Gerakan Modern Islam di Indonesia 1900-1942 (Jakarta: LP3ES, 1980), 40-42.

7 Situasi masa ini dapat dilihat dalam Yunan Yusuf, Corak Pemikiran Kalam Tafsir al-Azhar, (Jakarta: Pustaka Panjimas. 1990), 22-23.

8 Muhklis, Inklusifisme Tafsir, 34.

9 Hamka, Kenang-kenangan Hidup, Jilid I, 58. 
langsung dengan tokoh Islam terkemuka saat itu, pertama; Ki Bagus Hadikusumo; darinya Hamka, untuk pertama kali, memperoleh metode baru mempelajari tafsir, yaitu mementingkan maksud/kandungan ayat al-Qur'an, bukan membaca matan tafsir dengan nahwu yang tepat-sebagaiamana pengalamannya di Padang Panjang-. Ia juga bertemu dengan HOS Cokroaminoto (Pimpinan Syarikat Islam), RM. Suryopronoto dan Haji Fachruddin (Tokoh Muhammadiyah). Dari ketiga tokoh ini Hamka masing-masing mendapatkan nilai kehidupan yang berbeda-beda, Islam dan sosialisme, sosiologi, dan nama yang terakhiriamendapatkan kajian khusus 'Agama Islam'. ${ }^{10}$ Di Pekalongan, jasa Ahmad Rasyid Sutan Mansur tidak pernah dilupakan Hamka yang telah mempertemukannya dengan aktifis pemuda Islam Osman Pujotomo, Muhammad Rum dan Iskandar Idris. Secara keseluruhan, akumulasi pengaruh kedua tokoh itu (Ayah dan pamannya) dan tokoh lainnya turut membentuk mission, cita-cita hidup Hamka, yaitu "Bergerak untuk kebangkitan kembali umat Islam" ungkapnya sendiri. ${ }^{11}$

Kiprah Hamka dalam bidang keilmuan, memperoleh pengakuan dari beberapa Universitas terkemuka dunia. Tahun 1958 ia dianugerahi gelar Doctor Honoris Causa oleh Universitas Al-Azhar, Mesir dengan pidato pengukuhan Pengaruh Muhammad Abduh di Indonesia. Gelar serupajuga disematkan Hamka oleh Universitas Kebangsaan Malaysia, pada tahun $1974 .^{12}$

Hamka wafat pada hari Jum'at pada tanggal 24 juli 1981 setelah menyelesaikan 84 judul buku meliputi bidang agama, filsafat, dan sastra ${ }^{13}$ yang ia tulis dalam jangka 57 tahun. Tidak lama sebelum wafat,
${ }^{10}$ Hamka, Kenang-kenangan Hidup, Jilid II, 90.
${ }^{11}$ Hamka, Kenang-kenangan Hidup, ..., 16.
12 Yunus Amirhamzah, Hamka Sebagai Pengarang Roman (Jakarta: Puspita Sari Indah. 1993), 6-7.

${ }^{13}$ Selain karya tentang keagamaan, produktifitas Hamka dalam bidang yang lain dapat dibaca dalam ketat anegaraan seperti Negara Islam diterbitkan oleh Anwar Rasyid,Urat Tunggang Pancasila diterbitkan oleh Keluarga, Jakarta. Kemudian dalam filsafat seperti Mutiara Filsafat, dan Falsafah Ideologi Islam keduanya diterbitkan oleh Wijaya Jakarta, Lembaga Hikmat oleh Pustaka Keluarga. Dalam bidang Sejarah; Sejarah Umat Islam terdiri dari empat jilid penerbit NV Nusantara, Sejarah Islam di Sumatera diterbitkan Pustaka Nasional Medan dan Bulan Bintang Jakarta. Kategori Kisah seperti Tinjauan di Lembah Nil terbit di Jakarta oleh 
ia mengundurkan diri dari jabatan ketua umum MUI, sehubungan dengan kontroversi fatwa keharaman keikutsertaan umat Islam dalam perayaan Natal. Namun pemerintah (dalam hal ini Menteri Agama RI) keberatan dengan fatwa tersebut dan memerintahkan MUI untuk mencabutnya. Meskipun pada akhirnya fatwa tersebut dicabut, namun perlu dicatat ungkap Hamka "Fatwa boleh dicabut, tetapi kebenaran tak bisa diingkari. ${ }^{14}$

Catatan dan kepribadian yang tak bisa dibantah dari sosok Hamka adalah kegigihan dan keuletannya, begitu juga sebagaimana Gus Dur menulis “bahwa pada dasarnya Buya Hamka adalah seorang optimistis, dan dengan modal itulah ia mampu untuk terus-menerus menghargai orang lain secara tulus, karena ia percaya bahwa pada dasarnya manusia itu baik". ${ }^{15}$

\section{Membahas Tafsir Al-Azhar}

\section{Latar Belakang dan Riwayat Penulisan}

Perlu dipahami lebih awal bahwa, dalam genealogi intelektual, setiap pemikiran selalu merupakan aksi sekaligus reaksi terhadap wacana yang sudah ada. ${ }^{16}$ Pernyat aan tersebut tersebut ketika dikaitkan dengan Tafsir al-Azhar, akan menciptakan satu pertanyaan. Mengapa dan apa motivasi Hamka dalam menyusun karya tafsir tersebut?

Jika dirunut ke belakang, kandungan Tafsir Al-Azhar, sebenarnya berasal dari ceramah at au kuliah subuh Hamka yang disampaikannya di

Gapura, Mandi Cahaya di Tanah Suci, Di Tepi Sungai Dajlah, dan Empat Bulan di Amerika, kesemuanya diterbitkan oleh Tintamas Jakarta. Kemudian kategori nove yang dikenal adalah Menunggu Beduk Berbunyi (Jakarta: Pustaka Antara). Roman juga tidak luput dari karya Hamka seperti Tenggelamnya Kapal Van Der Wijk dan Di Bawah Lindungan Ka'bah. Sedangkan kumpulan cerita pendek terekam dalam Dalam Lembah Kehidupan dan Cermin Kehidupan, yang masing-masing diterbitkan oleh Balai Pustaka dan Mega Bokkstore, Jakarta. Sides Sudyarto, "Hamka, Realisme Religius", 140..

${ }^{14}$ Hamka, Tasawuf Modern,..,159.

15 Abdurrrahman Wahid "Benarkah Hamka Seorang Besar" dalam Tamara dkk, Hamka Di Mata Hati Umat..., 47.

16 Ahmad Norma Permata "Hermeneutika Fenomenologis Paul Riceour" dalam Paul Riceour, Interpretation Theory. Terj. Musnur Hery (Yogyakarta: Ircisod. 2012), 214 
Masjid Agung Al-Azhar, Jakarta, sejak tahun 1959. ${ }^{17}$ Kupasan Hamka mengenai tafsir al-Qur'an setelah shalat subuh tersebut kemudian dimuat secara teratur dalam majalah Gema Islam yang dipimpin oleh Jenderal Sudirman dan Kolonel Muchlas Rowi. ${ }^{18}$ Meskipun dalam perjalanannya, Hamka kemudian melanjutkan dan menyelesaikan tafsir tersebut dalam tahanan Karena ditangkap oleh penguasa orde baru selama dua tahun.

Sebagaimana pengakuan Hamka sendiri dalam muqaddimahnya, bahwa penamaan karya tafsirnya tersebut dengan Tafsir Al-Azhar dilatar belakangi beberapa faktor, diantaranya adalah bahwa tafsir tersebut merupakan kajian di Masjid Agung Al-Azhar sendiri, dan alasan yang kedua adalah merupakan sebuah penghargaan dan bentuk terimakasih kepada Al-Azhar Mesir yang telah menganugerahkannya gelar ilmiah yang disebutnya Ustdziyah Fakhriyah (Doktor Honoris Causa). ${ }^{19}$

Ada beberapa poin yang menjadi kegelisahan akademikmasyarakat yang sangat mendesak Hamka dalam menulis karya tafsir ini. Pertama, meningkatnya semangat dan minat anak muda Indonesia (daerahMelayu)dalammendalami agamaIslamsaat itu, terut amakajian tentang kandungan al-Qur'an. Namun semangat tersebut menurutnya tidak diimbangi dengan penguasaan bahasa Arab yang cukup. Kedua, banyaknya Muballigh atau ustaz dakwah yang 'bergentayangan' saat itu, namun masih canggung dalam menyampaikan dakwah mereka. Disatu sisi retorika mereka cukup bagus, namun ilmu umum dan alQur'an masih menjadi pertanyaan. Begitu juga sebaliknya. Kedua entitas ini, tutur Hamka, menjadi sasaran utama dan alasan penulisan Tafsir al-Azhar. ${ }^{20}$

\section{Sumber Tafsir}

17 Sebelumnya, Masjid ini lebih dikenal dengan nama Masjid Agung Kebayoran Baru, namun dengan kunjungan Mahmud Shaltut, Rektor Universitas Al-Azhar akhirnya masjid tersebut diberi nama Masjid Al-Azhar. Lihat Hamka, Tafsir Al-Azhar,..., 48.

18 Yunan Yusuf, Corak Pemikiran Kalam,, 53-54.

${ }^{19}$ Hamka "Mengapa Dinamai Tafsir Al-Azhar", dalam Hamka, Tafsir AlAzhar ,.... Jilid I, hlm. 48

${ }^{20}$ Hamka, Tafsir Al-Azhar (Jakarta: Pustaka Panjimas. 1983) Juz I, hlm. 4 
Setelah memperhatikan retorika penafsiran dalam menafsirkan al-Qur'an, seluk beluk dan sumber penafsiran, penulis berkesimpulan bahwa sumber penafsiran dalam Tafsir al-Azhar dibagi dalam dua kategori, Primer dan Sekunder. Primer dimaksudkan bahwa, Hamka tidak lepas dari kaidah tafsir bi al-ma'tsur yakni menafsirkan alQur'an dengan al-Qur'an, sunnah dan perkataan para sahabat. ${ }^{21}$ Kemudian data sekunder adalah sumber rujukan yang dipakai Hamka dalam menjelaskan makna ayat yang diambil dari qaul tabi'in, kitabkitab tafsir konvensional sebelumnya, dan juga beberapa karya tafsir Indonesia tidak luput dari kajian perbandingannya.

Sumber rujukan tafsir yang digunakan Hamka dapat terbaca dalam kata pengantarnya, diantaranya: Tafsir al-Thabari karya Ibn Jarir al-Thabari, Tafsir Ibn Katsir, Tafsir al-Razi, Lubab al-Ta'wil Fi Ma'ani al-Tanzil, Tafsir al-Nasafi-Madariku al-Tanzil wa Haqa'iqu al-Ta'wil, karya al-Khazi, Fath al-Qadir, Nailu al-Athar, Irsyad alFuhul (Ushul Fiqh) karya al-Syaukani, Tafsir al-Baghawi, Ruhul Bayan karya al-Alusi, Tafsir Al-Manar karya Sayyid Rasyid Ridha, Tafsir al-Jawahir karya Tanthawi Jauhari, Tafsir Fi Zhilal al-Qur'an karya Sayyid Qutb, Mahasin al-Ta'wil karya Jamaluddin al-Qasimi, Tafsir al-Maraghi karya Syaikh al-Maraghi, Al-Mushaf al-Mufassar karya Muhammad Farid Wajdi, al-Furqan karya A Hassan, Tafsir al-Qur'an karya bersama H. Zainuddin Hamidi dan Fahruddin H.S, Tafsir al-Qur'anul Karim karya Mahmud Yunus, Tafsir An-Nur karya TM Hasbi as-Shiddiqie, Tafsir al-Qur'anul Hakim karya bersama HM Kassim Bakri, Muhammad Nur Idris dan AM Majoindo, al-Qur'an dan Terjemahan Depag RI, Tafsir al-Qur'anul Karim karya Syaikh Abdul Halim Hasan, H. Zainal Arifin Abbas dan Abdurrahim alHaitami, Fathurrahman Lithalibi ayati al-Qur'an karya Hilmi Zadah Faidhullah al-Hasani, Fath al-Bari karya Ibn Hajar al-'Asqalani, Sunan Abu Daud, Sunan al-Tirmizi, Riyadh al-Shalihin, Syarh al-Muhazzab karya Syaikh Nawawi, Al-Muwaththa' karya Imam Malik, Al-Umm dan al-Risalah karya Imam Syafi'i, al-Fatawa, al-Islam 'Aqidah wa al-Syari'ah karya Syaikh Mahmud Syalthut, Subulussalam fi Syarh

${ }^{21}$ Definisi seperti ini dapat ditemukan dalam Manna' Khalil Al-Qattan, Studi Ilmu-Ilmu Qur'an Terj. Mudzakir As (Bogor: Pustaka Litera Antar Nusa, 2007), 482-483. 
Bulug al-Maram karya Amir Ash-Shan'ani, al-Tawassul wa al-Wasilah karya Ibn Taimiyah, Al-Hujjatul Balighah karya Syah Waliyullah alDihlawi, dan lain lain. ${ }^{22}$

\section{Metode dan Karakteristik Penafsiran}

Metode yang dipakai dalam Tafsir Al-Azhar, secara umum sebenarnya tidak jauh berbeda dengan karya-karya tafsir lain yang

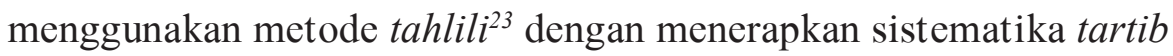
mushafi. Namun karena penekanannya terhadap operasionalisasi petunjuk al-Qur' an dalam kehidupan umat Islam secara nyata inilah maka tafsir ini bisa dikatakan berbeda dengan tafsir-tafsir sebelumnya. Khususnya dalam mengaitkan penafsiran dengan memberikan porsi yang lebih besar terhadap sejarah dan peristiwa-peristiwa kontemporer. ${ }^{24}$

Disamping itu, sebagaimana kesimpulan Howard M. Federspiel bahwa, tafsir Hamka ini memiliki ciri khas sebagaimana karya tafsir Indonesia sezamannya yakni dengan penyajian teks ayat al-Qur'an dengan maknanya, dan pemaparan dan penjelasan istilah-istilah agama

${ }^{22}$ Hamka, Tafsir Al-Azhar,.. Juz I, 331-332.

${ }^{23}$ Alfarmawi membagi metode tafsir menjadi empat macam. Pertama, Tahlili, yang disebut juga dengan metode tafsir Tajzi 'i, yakni menjelaskan kandungan alQur' an dari bebagai aspek dengan memperhatikan runt ut an ayat-ayat yang tercant um dalam mushaf mulai dari kosakata, asbabnuzul, munasabah dan lainnya. Kedua, tafsir Maudhu'i, yang berawal dari adagium 'biarkan al-Qur'an berbicara dengan dirinya sendiri". Dalam metode ini seorang mufassir ditunt ut untuk menghimpun ayat-ayat terkait topik yang menjadi kajian peneltian, kemudian pada kegiatan penafsiran baru dilakukan sesuai dengan kaidah yang berlaku pada umumnya. Ketiga, tafsir Ijmali, yakni menafsirkan al-Qur'an dengan global, tidak bertele-tele sebagaimana tahlili. Tafsir dengan metode ini tetap dilakaukan dengan strukt ur mushafi dengan penyajian bahasa yang ringkas dan sederhana dengan tujuan dapat dikonsumsi oleh khalayak umum. Keempat, tafsir dengan metode Muqarin, yakni langkah-langkah menafsirkan al-Qur'an dengan memperbandingkan sekelompok ayat yang terlihat bertentangan, atau ayat dengan hadis begitu juga memperbandingkan pendapat-pendapat para ulama mufassir dalam menafsirkan sebuah ayat namun dengan memperlihatkan letak perbedaan dari objek yang dibandingkan. Dari keempat metode diatas, metode pertama dan kedua merupakan metode yang lebih popular dikalangan para mufassir. Lihat Abd al-Hayy al-Farmawi, Al-Bidayah fi Tafsir Al-Maudhu'i (Mesir: AlMaktabah Al-Jumhuriyyah, 1992), 22.

${ }^{24}$ Howard M Federspiel, Kajian-kajian al-Qur'an di Indonesia, (Bandung: Mizan. 1996), 142. 
yang menjadi bagian-bagian tertentu dari teks serta penambahan dengan materi pendukung lain untuk membantu pembaca lebih memahami maksud dan kandungan ayat tersebut. ${ }^{25}$ Dalam tafsirnya ini, Hamka seakan mendemonstrasikan keluasan pengetahuan yang ia miliki dari berbagai sudut ilmu agama, ditambah pengetahuan sejarah dan ilmu non agama yang sarat dengan obyektifitas dan informasi.

Kemudian, apabila kita meneliti dan melihat secara intensif terhadap alur penafsiran Tafsir Al-Azhar ini, maka dengan segera kita akan membenarkan tesis sementara banyak peneliti yang telah berhasil mendudukkan bahwa ada kesamaan metode dan alur antara Hamka dengan Muhammad Abduh dan Sayyid Rasyid Ridha ketika menulis Tafsir Al-Manar-nya. Mengenai kesamaan ini, lebih awal sebenarnya Hamka mempertegas bahwa dalam penyusunan tafsirnya ia 'berkiblat' pada metode penafsiran yang dipakai dalam Tafsir Al-Manar, sehingga tidak heran jika corak penafsirannya-pun mirip dengan tokoh Tafsir Al-Manar tersebut.

"Tafsir yang amat menarik hati penafsir buat dijadikan contoh ialah tafsir al-Manar karangan Sayyid Rasyid Ridha, berdasarkan ajaran tafsir gurunya Muhammad Abduh. Tafsir beliau ini selain dari menguaraikan ilmu berkenaan dengan agama, mengenai hadis, fiqih dan sejarah dan lain-lain, juga menyesuaikan ayat itu dengan perkembangan politik dan kemasyarakatan yang sesuai dengan zaman diwaktu tafsir itu dikarang", ${ }^{26}$

Terlihat jelas, dengan alur penafsiran yang digunakan, Tafsir AlAzhar memiliki corak-sebagaimana dalam ilmu tafsir- digolongkan kedalam corak adab al-ijtima'i (corak sastra kemasyarakatan), yaitu corak tafsir yang menitik beratkan pada penjelasan ayat-ayat al-Qur'an dari segi ketelitian redaksinya, kemudian menyusun kandungannya dalam suatu redaksi yang indah dengan menonjolkan aspek petunjuk al-Qur'an bagi kehidupan, serta mengaitkan pengertian ayat-ayat dengan hukum alam (sunnatullah) yang berlaku dalam masyarakat. ${ }^{27}$

${ }^{25}$ Howard M Federspiel, Kajian-kajian Al-Qur'an, ..., 143.

${ }^{26}$ Hamka, Tafsir Al-Azhar,.. , 41.

27 'Abd al-Hayy al-Farmawi, Al-Bidayah al-Tafsir al-Mawdhu'i, (Kairo: Al-Hadlarah al-'Arabiyah, 1977), hlm. 23-24. al-Dzhabai, Tafsir wa al-Mufassirun 
Dengan kata lain, bahwa tafsir jenis ini bertujuan untuk memahami dengan maksud dan tujuan untuk menghidupkan nilai-nilai al-Qur'an dalam masyarakat Islam yang lebih nyata.

\section{Sistematika dan Langkah-langkah Penafsiran}

Perlu dipahami lebih awal bahwa, dalam penafsiran dikenal adanya tiga metode penulisan terhadapnya, mushafi, nuzuli, dan maudhu'i ${ }^{28}$ Ketiga metode penulisan tersebut masing-masing memiliki ciri khas yang berbeda satu sama lain. Kemudian, sebagaimana yang telah penulis singgung diatas, bahwa dari ketiga metode tersebut Tafsir Al-Azhar mengambil langkah sistematika mushafi, yakni penulisan atau penafsiran yang berpedoman pada tartib mushaf 30 juz, dimulai dari surat al-Fatihah sampai surat al-Nas.

Dalam pada itu, sebelum memberikan penafsirannya, Hamka terlebih dahulu memberikan pengantar dan muqaddimah untuk khalayak pembaca. Ini sangat penting, karena dilihat dari materi yang dibawakan dalam muqaddimah tersebut, sebagian besar-kalau tidak dikatakan semuanya- merupakan informasi atau pengantar yang harus diketahui sebelum membaca sebuah karya tafsir. Misalnya, dalam pengantar tersebut Hamka memberikan pandangan mengenai al-Qur'an, I'jaz al-Qur'an, Isi Mu'jizat al-Qur'an, al-Qur'an; lafaz dan Makna, kemudian historisitas tafsir yang berisikan, latar belakang dinamakan tafsir al-Azhar, haluan tafsir, dan diakhiri dengan petunjuk pembaca. ${ }^{29}$

(Kairo: Dar al-Kitab al-Haditsah, 1962), Juz 3, 213.

${ }^{28}$ Sistematika mushafi yakni penulisan kitab tafsir dengan berpedoman pada tartib mushaf yang dibakukan yakni mushaf 'Utsmani (dimulai dari surat al-Fatihah sampai surat al-Nas). Contoh kitab tafsir konvensional kebanyaka menggunakan sistematika ini, seperti Tafsir al-Thabari, Tafsir Ibn Katsir dan lain-lain. Kemudian yang dimaksudkan dengan sistematika nuzuli adalah penulisan kitab tafsir disesuaikan dengan kronologi turunnya surah-surah al-Qur'an. 'Abid al-Jabiri dalam karyanya Fahm al-Qur'an dan Muhammad Izzah Darwazah dengan kitabnya Tafsir al-Hadis merupakan represent asi dari contoh sistematika nuzuli tersebut. Sedangkan sistematika maudhu'i adalah menafsirkan al-Qur' an berdasarkan topik-topik tertentu dengan mengumpulkan ayat-ayat yang berkaitan dengannya kemudian ditafsirkan. Indal Abror "" dalam Muhammad Yusuf dkk, Studi Kitab Tafsir; Menyuarakan Teks yang Bisu (Yogyakarta: Teras. 2004), 68.

${ }^{29}$ Lihat dalam daftar isi, Hamka, Tafsir Al-Azhar,.. Juz I, 4 V. 
Sementara dalam penafsirannya, format sajiannya adalah, Pertama, menyebut nama surat dan artinya, nomor urut surat dalam susunan mushaf, jumlah ayat dan tempat diturunkannya surat. Kediua, mencantumkan empat sampai lima ayat (disesuaikan dengan tema atau kelompok ayat) dengan teks arab, yang kemudian diterjemahkan kedalam bahasa Indonesia-Melayu. Ketiga, Hamka memberikan kode "pangkal ayat" dan "ujung ayat" ketika sudah terjun dalam dialektiaka tafsir, ini digunakannya semata untuk memberikan kemudahan pembaca. Pernyataan tersebut dapat dilihat dalam contoh penafsiran Hamka dalam menafsirkan Surat An-Naba ayat 4:

“Jangan!" (pangkal ayat 4). Artinya tidaklah ada perlunya dipertengkarkan atau mereka tanya-bertanya dalam soal yang besar itu, karena; "Kelak mereka akan tahu." (ujung ayat 4). Tegasnya kalau mereka bertengkar atau tanya-bertanya dalam persoalan yang besar itu, sehingga keput usan tidak ada, namun akhir kelaknya mereka pasti akan tahu juga, atau segala yang mereka tanya-bertanyakan itu tidak lama lagi pasti menjadi kenyataan, karena ketentuan yang digariskan oleh Allah, tidak ada tenaga manusia yang dapat rnenahannya. ${ }^{30}$

Sedangkan mengenai langkah penafsiran yang diambil Hamka, sementara penulis berkesimpulan bahwa dalam menafsirkan al-Qur'an Hamka telah sukses mendemonstrasikan keilmuannya yang diterapkan dalam kaidah-kaidah penafsirannya. Sementara penulis merangkum langkah-langkah penafsiran Hamka sebagai berikut:

a. Menerjemahkan ayat secara utuh disetiap pembahasan,

b. Memberikan penjelasan masing-masing dari nama surat dalam al-Qur'an disertai dengan penjelasannya secara komprehensif.

c. Memberikan tema besar ketika setiap ingin membahas tafsiran terhadap kelompok ayat yang menjadi sajian.

d. Kegiatan penafsiran dilakukan dengan menjelaskan ayat-perayat sesuai dengan kelompok ayat yang sudah ditentukan.

${ }^{30}$ Hamka, Tafsir Al-Azhar,.. Juz XXX, 7. 
e. Menjelaskan munasabah (korelasi) antar ayat dengan ayat lainnya, begitu juga terkadang mengemukakan korelasi antar surat.

f. Menjelaskan asbab al-Nuzul (riwayat sebab turun ayat) jika ada. Dalam pemaparannya tentang asbab al-Nuzul tersebut, Hamka seringkali memberikan berbagai macam riwayat berkenaan dengan ketentuan turunnya ayat tersebutmeskipun terkadang tanpa adanya usaha klarifikasi dari Hamka sendiri.

g. Memperkuat penjelasannya dengan menyitir ayat lain atau hadis Nabi Saw. yang memiliki kandungan makna sama dengan ayat yang sedang dibahas.

h. Memberikan butiran-butiran hikmah atas satu persoalan yang dianggapnya krusial dalam bentuk pointers. ${ }^{31}$

i. Mengaitkan makna dan pemahaman ayat dengan problema sosial masyarakat kekinian.

j. Memberikan kesimpulan (khulashah) disetiap akhir pembahasan penafsiran.

Dengan metode dan langkah penafsiran diatas, terlihat Hamka tidak terlalu tertarik untuk memperhatikan makna ayat dilihat dari segi balaghah, nahwu, sharf dan lainnya, demikian tersebut dikarenakan sangat memperhatikan kontekstualitas ayat al-Qur'an. Hal demikian, berangkat dari porsi asbab nuzul dan usaha kontekstualisasi pemahaman dengan keadaan masyarakat terlihat lebih besar. Namun, perlu dicatat, Hamka tidak mengambil langkah tersbut tidak berarti meninggalkannya sama sekali (ma la yudraku kulluh la yutraku kulluh), ini dikarenakan dibeberapa tempat Hamka juga berupaya menjelaskan makna kosakata tertentu secara etimologis dalam suatu ayat, begitu

${ }^{31}$ Pernyataan ini dapat dilihat ketika Hamka memberikan lima hikmah dari iman kepada hari akhirat tatkala menafsirkan penggalan kedua ayat 4 dalam surat al-Baqarah (wabil akhirati hum yuqinun), namun langkah seperti ini tidaklah baku. Artinya tidak setiap akhir penafsiran atas satu ayat mesti diakhiri dengan pemberian buturan-butiran hikmah dalam bentuk pointers. Sebagaimana dalam ayat 1 sampai ayat 3 dari surat al-Baqarah tidak ditemukan bentuk pointers semacam itu. Baru pada ayat 4 kita temukan. Pada ayat 5 juga tidak ada. Ini menandakan bahwa langkah itu sifatnya situasional. 
juga dalam melihat perbedaan qira'ah dan implikasi pemaknaan yang ditimbulkan atasnya. ${ }^{32}$

\section{Catatan Penulis}

Hamka dan karyanya Tafsir Al-Azhar merupakan dua entitas yang tidak bisa dipisahkan. Tanpa mengenal sosok Hamka, besar kemungkinan akan sulit memahami karya tafsirnya. Dalam pentas sejarah Islam Indonesia, kedua entitas tersebut telah 'menyita' waktu umat Islam Indonesia. Dengan sosok yang bijaksana dan alim, serta karya yang luas wawasan, jelas memperoleh perhatian tersendiri dari umat Islam Indonesia. Hal ini antara lain terbukti dengan banyaknya akademisi maupun masyarakat biasa yang menjadikan tafsir ini dan penulisnya (Hamka) sebagai bahan diskusi atau objek kajian dalam peneliatan serta majelis ta'lim. Dari kegiatan tersebut pula dengan sendirinya, melahirkan banyak catatan berupa komentar dan pujian.

Sampai pada titik ini, penulis melihat bahwa Hamka sangat getol mengajak umat Islam dalam menyuarakan tafsir kontekstual. Tafsir yang selaras dengan keadaan dan perkembangan zaman. Usaha tersebut sangat kentara dalam rentetan langkah penafsirannya yakni tidak memisahkan tekstual ayat, asbab nuzul, dan konteks. Hubungan antara ketiga entitas tersebut sangat memiliki keterkaitan mendasar dalam memahami al-Qur'an secara menyeluruh, dan tidak bisa dipisahkan.

${ }^{32}$ Sebagai contoh dalam menafsirkan ayat 2 surat al-Baqarah, Hamka menjelaskan arti kata 'al-Muttaqin' yakni dengan mencari akar kata 'Taqwa'. Dalam penjelasannya, kata Taqwa diambil dari kata wiqayah yang memiliki makna memelihara. Memelihara dalam terapannya dimaknai dengan memelihara hubungan baik manusia dengan Tuhan, yakni jangan sampai terjerembab kedalam perbuatan yang dilarang oleh Tuhan, dari kata tersebut lahirlah definisi taqwa sebagaimana yang masyhur dalam teologi islam yakni, memelihara segala bentuk perintah Tuhan. Begitu juga dalam menjabarkan makna kata Islam dalam menafsirkan Ali Imran 19. Dalam tefasirnya tersebut Hamka memaparkan bahwa kata islam terdiri dari tiga huruf Sin Lam Mim yang berate selamat, sejahtera, damai dan bersih dari segala sesuatu, maka pengertian dasar Islam adalah menyerahkan diri kepada Allah dengan tulus murni. Setiap orang yang telah sampai kepada Allah maka dia telah mencapai islam, karenanya, bolehlah dikatakan bahwasanya islam itu adalah persatuan umat manusia dalam penyerahan diri kepada Tuhan. Islam dalam hakikat aslinya tidak mengenal perbedaan kulit dan nasab. Lihat Hamka, Tafsir Al-Azhar, Juz I hlm. 122123, juga Juz III, 225. 
Dengan kenyataantersebut, sebenarnyatidaksalahjikadikatakan bahwa Hamka telah mengaplikasikan upaya hermeneutika dalam karya pembacaannya terhadap al-Qur'an. Karena bagaimanapun, konsep hermeneutika-dalam makna yang sempit-merupakan usaha pembacaan al-Qur' an yang tidak hanya memberikan pemaknaan terhadap tekstual suatu ayat, namun memberikan pemkanaan kembali (reproduksi) suatu ayat terhadap keadaan (realita) dimana al-Qur'an ditafsirkan.

\section{Contoh Penafsiran}

Untuk lebih memperjelas pemahaman terkait sub bab diatas, penulis akan menampilkan beberapa contoh penafsiran Hamka dalam karya tafsirnya.

a. Surat al-Fiil ayat 4

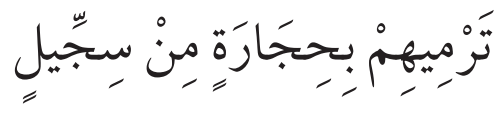

"yang melempari mereka dengan batu siksaan"

Dalam menjelaskan ayat diatas, Hamka sebenarnya memberikan pengant ar bahwa adanya perbedaan pendapat para ahli tafsir mengenai 'batu siksaan' diatas, ${ }^{33}$ namun Hamka terlihat tidak mengungkapkan lebih jauh. Terlepas dari perbedaan tersebut, Hamka disini terlihat menegaskan posisinya dalam mendukung pendapat Muhammad Abduh, yakni memaknainya dengan 'penyakit cacar'. Dengan menyitir keterangan dari Ikrimah, bahwa memang adanya penyakit cacar tersebut baru ada sejak peristiwa ekspansi Abrahah al-Asyram al-Habasyi dalam menghancurkan Ka'bah.

Lebih jauh, Hamka mengkontekskan dengan masa sekarang bahwa, memang jika kita membawa burung dari daerah dan at au negara yang berbeda maka akan lebih baik dengan melakukan pemeriksaan kemanan terlebih dahulu, yakni ke dokter. Hal ini didorong dengan berbagai macam penyakit yang merajalela di seluruh dunia saat ini, diantaranya adalah Flu Burung. ${ }^{34}$

33 Perbedaan pendapat seputar ayat diatas dapat dibaca dalam Tafsir alMishbah. Volume 15, hlm 620-623

${ }^{34}$ Hamka, Tafsir Al-Azhar,..Juz XXX190 
b. Surat al-Mumtahanah ayat $8-9$

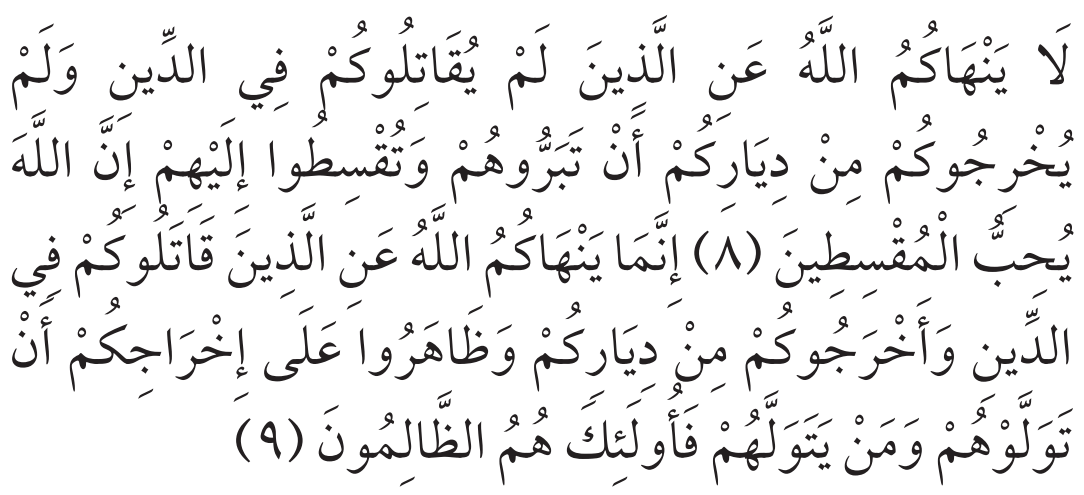

Tidaklah Allah melarang kamu terhadap orang-orang yang tidak memerangi kamu pada agama dan tidak mengusir kamu dari kampong halaman kamu, bahwa kamu berbaik dengan mereka dan berlaku adil terhadap mereka; sesungguhnya Allah suka kepada orang-orang yang berlaku adil (8), Yang dilarang kamu hanya terhadap orang-orang yang memerangi kamu dan mengusir kamu dari kampung halaman dan mereka bantu atas pengusiranmu itu, bahwa kamu menjadikan mereka teman. Dan barang siapa yang berkawan dengan mereka, maka itulah orangorang yang aniaya (9). ${ }^{35}$

Dalam menafsirkan ayat di atas, Hamka lebih awal mengedepankan latar historis turunnya ayat tersebut (Asbab Nuzul, yakni setelah perjanjian hudaibiah banyak orang Arab Quraisy yang menemui keluarganya yang telah berhijrah bersama Nabi ke Madinah. Diantaranya adalah Qutailah, Ibu dari Asma' yang tidak lain adalah bekas istri Abu Bakar. Ketika Qutailah menemui (karena sayang dan rindunya) dan memberikan hadiah kepada Asmaa', Asma merasa ragu akan pemberian ibunya tersebut, dikarenakan ibunya pada saat itu belum masuk Islam. Hal ini ditanyakan kepada Rasulullah Saw. maka turunlah ayat di atas.

Berpijak dengan asbab nuzul dan kerangka penafsirannya yang lain, pada akhirnya Hamka menyimpulkan bahwa ayat di atas dan dua ayat sebelumnya adalah pedoman bagi umat islam untuktoleransi dalam tataran praktis dengan umat agama lain. Menurutnya, dipersilahkan

${ }^{35}$ Hamka, Tafsir Al-Azhar,... juz XXVIII, 130. 
kepada umat Islam untuk bergaul dengan akrab, bertetangga, saling tolong menolong, bersikap adil dan jujur kepada pemeluk agama lain. Tetapi jika ada bukti bahwa pemeluk agama lain itu hendak memusuhi, memerangi dan mengusir umat Islam, maka semua yang diperbolehkan it u menjadi terlarang. Meskipun mereka tidak memusuhi Islam namun membantu dalam memusuhi Islam, memiliki hukum yang sama, juga harus diperangi. ${ }^{36}$

Ahli-ahli tafsir menyatakan bahwa ayat ini adalah "Muhkamah" artinya berlaku buat selama-lamanya, tidak dimansukhkan. Dalam segala zaman hendaklah kita berbaik dan bersikap adil dan berjujur kepada orang yang tidak memusuhi kita dan tidak bertindak mengusir kita dari kampong halaman kita. Kita diwajibkan menunjukkan budi Islam kita yang tinggi terhadap siapapun, ${ }^{37}$

\section{Kesimpulan}

Tafsir Al-Azhar memiliki langkah dan karakteristik yang tidak jauh berbeda dengan beberapa kitab tafsir modern-kontemporer. Metode, corak serta langkah penafsiran yang Hamka ambil dalam memahami al-Qur'an telah memperlihatkan kesungguhannya dalam membumikan al-Qur'an dalam kehidupan Islam Indonesia yang lebih nyata dan kontekstual.

Akhirnya, keterbatasan waktu dan kemampuan penulis, merupakan alasan logis jika tulisan ini jauh dari kata sempurna. Karenanya penelitan lebih jauh tentang pemikiran tafsir dan geneologi pemikiran Hamka serta 'benturannya' dengan karya-karya seperti Al-Maraghi, Al-Manar, Fi Zhilal al-Qur'an dan yang lainnya perlu mendapat perhatian yang lebih intens dan obyektifdari pihak akademisi selanjutnya.

\footnotetext{
${ }^{36}$ Hamka, Tafsir Al-Azhar,... juz XXVIII, 136-138.

${ }^{37}$ Hamka, Tafsir Al-Azhar,... juz XXVIII, 137.
} 


\section{Daftar Pustaka}

Mustaqim, Abdul, Epistemologi Tafsir Kontemporer. Yogyakarta: Lkis. 2012.

Chirzin, Muhammad, Sayyid Qutb dan al-Taswir al-Fanni fi al-Qur'an (Penggambaran Artistik dalam al-Qur'an) dalam Jurnal Studi Ilmu-Ilmu al-Qur'an dan Hadis. Vol. III, No. 2, Januari 2003.

Nasir Tamara (ed), Hamka Di Mata Hati Umat, Jakarta: PT Sinar Agape Press. 1984.

Mukhlis, Inklusifisme tafsir Al-azhar, Mataram: IAIN Mataram Press.2004

Djauhari, Vincent (Editor), Hamka di Mata Hati Umat, Jakarta: Sinar Harapan, 1996.

Yusuf, Yunan, Corak Pemikiran Kalam Tafsir al-Azhar, Jakarta: Pustaka Panjimas, 1990.

Amirhamzah, Yunus, Hamka Sebagai Pengarang Roman, Jakarta: Puspita Sari Indah. 1993.

Riceour, Paul, Interpretation Theory. Terj. Musnur Hery, Yogyakarta: Ircisod. 2012.

al-Dzhabai, Tafsir wa al-Mufassirun, Kairo: Dar al-Kitab al-Haditsah, 1962.

Al-Qattan, Manna' Khalil, Studi Ilmu-Ilmu Qur'an Terj. Mudzakir As, Bogor: Pustaka Litera Antar Nusa, 2007.

al-Farmawi, Abd al-Hayy, Al-Bidayah fi Tafsir Al-Maudhu'I, Mesir: AlMaktabah Al-Jumhuriyyah, 1992.

Federspiel, Howard M, Kajian-kajian al-Qur'an di Indonesia, Bandung: Mizan. 1996.

Muhammad Yusuf dkk, Studi Kitab Tafsir; Menyuarakan Teks yang Bisu, Yogyakarta: Teras. 2004

Rusydi, Martabat dan Pribadi Prof. Dr. Buya Hamka, Jakarta: Panjimas, 1983.

Hamka, Kenang-kenangan Hidup, Jakarta: Bulan Bintang , Tasawuf Modern,.. , Tafsir Al-Azhar, Jakarta: Pustaka Panjimas. 1982.

, Hamka Di Mata Hati Umat, Jakarta: Pustaka Sinar Harapan. 1996. 